\title{
Differential Europeanization? Explaining the impact of the early warning system on subnational parliaments in Europe
}

\author{
KAROLINA BOROŃSKA-HRYNIEWIECKA ${ }^{1,2}$ * \\ ${ }^{1}$ Institute of Political Science, University of Wroctaw, Wroctaw, Poland \\ ${ }^{2}$ The Polish Institute of International Affairs, Warsaw, Poland
}

The inclusion of subnational parliaments into the early warning system (EWS) for subsidiarity control generates transforming dynamics in parliamentary modus operandi in European Union (EU) decentralized states. Empirical findings reveal considerable variations in the pace and scope of subnational parliamentary activity in EU policy control challenging the existing theories of territorial mobilization. Drawing from a comparative institutional analysis, this article offers a theoretical framework that permits accounting for cross-country variations in subnational parliamentary mobilization in EU affairs, under the EWS. By placing an increased focus on the domestic environment, it suggests that the two important factors which might affect the scope of parliamentary activity are (1) the relationship between the executive and legislature at the subnational level, and (2) the position of the regional executive in domestic governance arrangements.

Keywords: subnational parliaments; Europeanization; early warning system

\section{Introduction}

The Lisbon Treaty recognizes, for the first time, subnational parliaments with legislative powers ${ }^{1}$ as a separate category of democratic institutions with the right to participate in the control of the European Union's (EU) legislative process. Protocol no. 2 on the application of the principles of subsidiarity and proportionality attached to the Treaty of Lisbon (Protocol no. 2 TL) includes subnational parliaments into the so-called 'early warning system' (EWS) in which national parliaments scrutinize EU legislative projects in terms of their compliance with the principle of subsidiarity. ${ }^{2}$ Such institutional innovation not only extends the EU

1 There are currently 74 subnational parliaments in the EU exercising constitutionally attributed lawmaking competences in various fields of policy. They can be found in eight EU member states (Austria, Belgium, Germany, Spain, Italy, United Kingdom, Portugal - Madeira and Azores, and Finland - Åland Islands).

${ }^{2}$ Under the EWS, national parliaments have 8 weeks from the date of transmission of an EU draft legislative act to scrutinize it and issue a reasoned opinion stating why they consider that the draft in question does not comply with the principle of subsidiarity. Depending on the number of reasoned opinions, the Commission might have to reconsider, amend, or withdraw its proposal (Articles 6-7 of Protocol no. 2).

* E-mail: kboronska@hotmail.com 
channel of representative democracy to the subnational level, but also generates new inter-institutional dynamics in decentralized EU member states.

The empirical findings reveal considerable variations in the pace and scope of subnational parliamentary activity under the EWS challenging the existing theories of territorial mobilization. Contrary to what could be expected, subnational parliaments of less decentralized states seem to be more active and thus 'Europeanize' faster than their counterparts in federal states. Shedding light on these variations and the way in which subnational parliaments interact with other institutional actors, such as subnational governments and national parliaments, is necessary to further our understanding of the dynamics at play in the European multi-level policy process.

EU-oriented activities of subnational parliaments provide a relatively new and uncharted area of research (Abels, 2013; Bursens et al., 2013). To date, scholarship on subnational mobilization in the EU has been primarily focussed on local and regional governments (Bauer et al., 2010; Tatham, 2011; Callanan, 2012; Högenauer, 2014) or regional offices in Brussels (Jeffery, 1996; Marks et al., 2002; Rowe, 2011). Cases of subnational parliamentary activity have been analysed in single country studies and mostly from a legal perspective (Heggie, 2006; Palomares Amat, 2011; Carmona Contreras, 2012). To date, some comparative attempts to capture the role of regional parliaments under the EWS (Vara Arribas and Bourdin, 2011; Borońska-Hryniewiecka, 2013) have provided an institutional overview of the existing procedures but have lacked the explanatory framework accounting for variations in parliamentary mobilization patterns. Moreover, the existing theoretical frameworks for studying multi-level parliamentarism in the EU seem to overlook its subnational dimension, thus limiting the analysis to two-level relations between the European Parliament and national assemblies (Crum and Fossum, 2009; Neyer, 2014).

This article aims to fill this gap by addressing the question: what are the factors explaining differential parliamentary engagement of subnational parliaments in EU policy control? To this end, it proposes a theoretical framework and applies it to compare subnational parliamentary mobilization in the framework of the EWS in Germany, Spain, and the United Kingdom. The paper builds on the concept of Europeanization understood as a change in domestic governance structures as a consequence of the development of EU-level institutions. Such understanding of the concept allows this research to place an increased focus on the mediating role of domestic institutions and to identify factors affecting subnational parliamentary mobilization that have not been addressed so far in a single study. The analysis draws from the original data obtained from interviews and institutional documents.

The paper suggests that while intra-state differentiation among parliaments exists, the two domestic factors that might affect the scope and effectiveness of subnational parliamentary mobilization in the EWS are (1) the relationship between the executive

According to Protocol no. 2 TL, 'it will be for each national Parliament or each chamber of a national Parliament to consult, where appropriate, regional parliaments with legislative powers'. 
and legislature at the subnational level, and (2) the position of the subnational executive in domestic governance arrangements. The proposed analytical framework highlights the importance of the 'infrastructural context' of domestic institutional relations situated between the individual region's capacities and the constitutional status of the state. This often-overlooked meso-level of analysis is particularly important, as it is grounds for the interplay between the structure and agency.

The first section of this paper presents alternative explanations for subnational mobilization in EU affairs and their shortcomings in studying parliaments. The second section presents and discusses the theoretical framework and hypotheses that guide the empirical analysis. In the third section, an overview of the applied methodology and data sources is provided. Fourth section demonstrates how the proposed theoretical framework applies in comparative case studies. The article finishes with systematized conclusions and their implications for further research.

\section{State of the art and alternative explanations}

The literature on territorial mobilization in Europe provides alternative explanations about the scope of regional involvement in EU affairs. The majority of accounts perceive the constitutional strength of the regions, marked by the degree of a country's decentralization on the axis from unitary to federal state, as the main determinant of subnational mobilization. In this regard, it is assumed that higher levels of devolution result in stronger subnational mobilization in EU affairs (Marks et al., 1996; Hocking, 1997; Jeffery, 2000; Keating and Hooghe, 2006). As Donas and Beyers (2013: 7) explain, subnational mobilization is largely policy-seeking, and regions with larger portfolios of competencies, thus more affected by the implementation of EU law, need more information on EU policies compared with those with a smaller scope of competences. Alternatively, some authors find that a region's financial resources and economic position influence the scope and quality of subnational mobilization in the EU (Börzel 1999; Blatter et al., 2009; Tatham, 2010). Others point to 'cultural distinctiveness' as an important variable behind mobilization patterns (Marks et al., 1996: 181-185). The importance of the above-mentioned factors has been empirically confirmed with regard to regional influence in Brussels, especially to the activity of regional representation offices (Jeffery, 1996; Marks et al., 1996, 2002; Moore 2007; Blatter et al., 2009) and territorial interest associations (Donas and Beyers, 2013).

Yet, while valid for identifying regional patterns of external mobilization in EU affairs, these factors fail to explain the variations at the regional parliamentary level. They simply overlook or underestimate the domestic institutional context in which subnational parliaments operate. The constitutional status variable does not account for some clearly emerging cross-country patterns such as the relatively low degree of subnational parliamentary mobilization in federal states like Germany and Belgium, as compared with, for example, Spain or the United Kingdom. Regarding the individual-level variables, the research reveals that regions very active in Brussels, such as Lombardy [large gross domestic product (GDP); cultural 
distinctiveness] or North Rhine-Westphalia (large GDP), do not necessarily mobilize equally as strongly as in the domestic parliamentary arena. Some of the reasons lie in the fact that parliaments, as latecomers in the process of European integration, find themselves in a position of renegotiating their position vis-à-vis their governments. In this sense, parliamentary control of EU policy-making requires mobilization of different resources than those used by governments for external representation in Brussels.

This research agrees with and builds on several authors' opinion that territorial mobilization literature has to a certain extent neglected the domestic environment, which might catalyse or constrain regional action capacity in EU affairs (Jeffery, 1997, 2000; Marks et al., 2002; Rowe, 2011). To compensate for this shortcoming, Jeffery offers a more contextualized analytical framework focussing on other factors that might modify the level of mobilization across constitutional orders. He points to aspects such as the nature of intergovernmental relations between the national and subnational levels, the existence of multiple subnational structures with competing interests in EU-related matters, and the legitimacy of subnational actors' European policy mobilization (Jeffery, 2000: 12-14).

Applying such 'domestic lenses' to study parliamentary participation in the EWS seems especially relevant for two reasons. First, the EWS constitutes an internal (as opposed to external) access route to EU policy-making, as the inclusion of regional parliaments depends entirely on member states. Second, in the field of EU affairs, subnational parliaments are doubly embedded structures in the sense that they are dependent on their horizontal relations with subnational governments and on their vertical relations with national parliaments. For these reasons, any understanding of subnational parliamentary mobilization patterns must be rooted in the domestic perspective.

\section{Research expectations}

The central theoretical idea of this paper is that subnational parliamentary mobilization is shaped by the overall context in which parliaments operate. In order to explain what specific factors might influence the differential parliamentary mobilization under the EWS, this paper makes three following claims. First, the EWS presents an Europeanization mechanism in the sense that it induces certain adaptive responses from regional parliaments resulting in different forms of mobilization. Second, in line with the Europeanization literature (Börzel and Risse, 2000; Featherstone and Radaelli, 2003), it is assumed that the EWS exerts some influence upon the hitherto established relations between domestic actors. In this sense, transposition of the EWS induces new patterns of interactions between the central and subnational authorities, as well as between executives and legislatures, not infrequently leading to challenging the wellestablished hierarchies. The affected domestic structures include power relations between government levels (national-subnational) as well as between horizontal institutions (i.e. legislature-executive) (Bursens and Deforche, 2007). As a result of 
some degree of 'misfit' between the newly established European rules and the 'old' domestic-level processes, the EWS produces a certain 'inconvenience' among the domestic actors that constitutes adaptational pressures (Börzel and Risse, 2000). Third, the changes induced by the EWS are conditioned by some mediating factors inherent in the domestic institutional structures. In this sense, the outcome of Europeanization, that is, the nature of subnational parliamentary mobilization, is determined by a complex configuration of institutionally based variables.

\section{The 'EWS' as an Europeanization mechanism}

For the purpose of this research, Europeanization will be defined here as the institutionalization of formal and informal rules, procedures and 'ways of doing things', first, defined at EU level and then incorporated into domestic contexts (Radaelli, 2003: 30). Additionally, in line with rational choice institutionalism, this paper claims that the EWS - as an Europeanization mechanism - constitutes a political opportunity structure that offers parliaments additional resources to exert influence, while constraining the ability of other actors to pursue their goals (Börzel and Risse, 2000).

First, the EWS becomes a catalyst for the exercise of the already attributed competences of subnational parliaments transferred to the EU, thus restoring their controlling and representative function. In this sense, the EWS becomes a legislative transmission belt between the Commission, the member states' parliaments, and the subnational assemblies, who through cooperation and exchange of views reinforce each other's legitimacy. Second, the EWS was created to address the problem of democratic deficit and lack of accountability of the EU. The subsidiarity scrutiny procedure was to become the way in which the EU legislator justifies his actions before the forum of national (and subnational) parliaments under the threat of consequences (i.e. 'yellow' or 'orange card'). ${ }^{3}$ Some authors have even compared the mechanism with a 'virtual third chamber' collectively fulfilling the legislative, representative, and deliberative functions in the EU (Cooper, 2012). Finally, Protocol no. 2 TL, for the first time, provides subnational parliaments with a legal base for participation in the EU's legislative process. By establishing the first, albeit mediated, interface between subnational parliaments and the European Commission, the EWS becomes an opportunity structure for subnational parliaments to gain visibility in EU affairs, renegotiate their controlling powers vis-à-vis subnational executives, and to become direct interlocutors vis-à-vis national parliaments.

\footnotetext{
3 According to Protocol no. 2 TL a 'yellow card' can be issued when at least one-third of national parliaments are opposed to the draft legislative act on the basis of its non-compliance with the subsidiarity principle. The initiator of the contested draft must review the proposal. He may then decide to maintain, amend, or withdraw the draft, although reasons must be given for each decision in the form of Communication. An orange card is issued when more than half of the national parliaments oppose such an act on grounds of subsidiarity breach. The draft must be reviewed and if the Commission decides to maintain it, it has to provide a reasoned opinion justifying why it considers the proposal to be in compliance with the subsidiarity principle. Eventually, it is the EU legislators (Council or the European parliament) who decide whether or not to block the Commission's proposal.
} 


\section{Theoretical assumptions and hypotheses}

Since Europeanization per se does not provide a theory from which hypotheses can be derived to explain the domestic adaptation (Bursens and Deforche, 2007), this research combines two different strands of the new institutionalism, that is, rational choice and the historical institutionalist approach, to identify the factors behind subnational parliamentary mobilization under the EWS. These two strands are used as a set of lenses to elucidate different aspects of the institutional behaviour of regional parliaments in response to the EWS (cf. Peters, 2000).

According to the rationalist institutionalist perspective, the extent to which actors adapt to Europeanization depends on the availability of their own resources as well as the anticipated behaviour of others (Börzel, 1999: 575). One of the two types of mediating factors affecting the outcome of adaptation is the existence of formal facilitating institutions (Börzel and Risse, 2000: 2) providing actors with the resources necessary to exploit the new opportunity structure. This research hypothesizes that, in the context of the EWS, such a facilitating function can be fulfilled by the relationship between the subnational parliament and its executive.

On the other hand, historical institutionalism explains how institutional traditions embedded over time influence the development of new governance styles and relations pointing to path dependence (Pierson, 2000: 252). It assigns more explanatory power to the organization and legacy of institutions than to the properties of individual actors (Olsen, 2009: 9). Historical institutionalism claims that the eventual institutional changes and development of new mechanisms and rules do not have an unbiased, neutral character but are rooted in particular institutional traditions and values. In this sense, it is expected that the established position of the subnational executive in domestic governance arrangements will be of crucial importance in determining the scope of the subnational parliamentary mobilization.

\section{The relationship between the executive and legislature}

European integration and the emergence of EU multi-level governance are widely thought to weaken parliaments and strengthen governments (Raunio, 2007). Regional governments have acquired more expertise in European affairs through participation in domestic decision-making as well as by representing their regions in Brussels. They possess the necessary resources that subnational parliaments are still lacking as 'latecomers' in the process of European integration. Taking that the EWS presents a unique opportunity structure to get access to EU policy-making, it is assumed that the extent to which parliaments are able to scrutinize and assess EU legislation depends on the two-fold character of the executive-legislature relationship: first, the distribution of formal competences between the two actors, and, second, their 'working relationship'.

In the first case, we are interested in the existence of formal institutions; that is written norms, rules, and procedures (Börzel, 1999: 575-579) that regulate the legislative action 
capacity under the EWS vis-à-vis the government. These rules primarily concern the right of subnational parliaments to timely information, consultation, and decision-making. They decide who is the protagonist in the EWS, that is, who receives the information first and who has the 'last say' in the procedure before issuing an opinion. Such rules are usually set up at the national level and vary across member states. In line with the rational choice approach, it is hypothesized that the existence of such legal resources will encourage parliamentary engagement in the scrutiny of EU legislation. In other words, the existence of formal participation and/or information rights established at the national level will increase subnational parliamentary mobilization under the EWS.

The second aspect of the same factor regards the way in which subnational governments interact with regional parliaments under the EWS. Taking for granted that parliaments quite often depend on their governments in terms of administrative resources, executives can either successfully facilitate, constrain, or even block effective parliamentary participation in the EWS by regulating access to information and expertise. In this sense, governments themselves become formal institutions affecting the scope of parliamentary adaptation (cf. Börzel and Risse, 2000: 7). This aspect of the executive-legislature relationship can be operationalized by looking at whether their 'working relations' are based on cooperation, resource dependence, domination, or perhaps competition, and whether there is expertise and information sharing or rather monopolization by either institution. ${ }^{4}$ In a cooperative institutional context, the government is likely to support the legislature in performing its EU scrutiny function and by becoming an interlocutor in contacts with the national parliament. Yet, competitive behaviour or monopolization of information by the executive might reduce parliamentary mobilization. From this, the second hypothesis can be formulated: cooperative relations between the subnational government and parliament will lead to a stronger subnational parliamentary mobilization under the EWS. Although, with time, executivelegislative relations are likely to evolve, the change is expected to be path dependent and its pace will be conditioned by a difficult process of mutual restructuring.

\section{Position of the subnational executive in domestic governance arrangements}

Drawing from historical institutionalism, it is expected that while institutional actors tend to be rational in their actions, their capacity to change or adapt is conditioned by the pre-existing institutional frameworks (March and Olsen, 1989; Olsen, 2009). In this regard, the stronger the institutionalization of certain governance traditions, the higher the resistance to change and institutional reorganization (Selznick 1957: 17).

\footnotetext{
4 In order to measure the 'working relationship' variable, two questions were asked in the questionnaire: (1) Did you establish a coordination mechanism with your regional executive? If yes, what kind? (2) In your opinion, cooperation with the regional executive in the EWS has so far been: very good, good, mediocre, poor.
} 
Not only does the existence of rules matter here, but also the general belief about the legitimate character of such rules and the distribution of competences resulting from them (Olsen, 2009: 10-13). In this context, authors studying subnational mobilization emphasize that the impact of the EU is strongly mediated by the established traditions of central-local relations (Callanan, 2012) and power balances between particular domestic actors (Jeffery, 2000; Bursens, 2008).

Assuming that subnational governments might constitute facilitating institutions, their position in domestic governance arrangements plays a crucial role in conditioning the action capacity of parliaments in EU affairs. This position might be operationalized in several ways. One of the indicators might be the nature of the domestic relationship between the regional and central-level decision-makers, that is whether regional interests are negotiated in formalized fora open to parliamentary scrutiny, or whether they are rather agreed through informal relations between subnational and national ministers, conducted 'behind closed doors' and in a confidential manner. In the latter case, if subnational governments are used to monopolize information, parliamentary powers become severely restricted and limited to rubber-stamping executive decisions. Another indicator for measuring the position of the regional executive in domestic governance arrangements might be the composition of the second chamber. In decentralized states, the domestic relationship between the regional and central-level decision-makers is often related to the role of the second chamber representing territorial interests at the national level (Russel, 2001; Swenden, 2004, 2010). Second chambers are also crucial players in subsidiarity control, as they can cast one independent subsidiarity vote under the EWS. Territorial second chambers can then voice subnational concerns in ex ante EU policy control. However, if the second chamber is composed of members of regional governments (not parliaments), the situation becomes complicated. It might be that instead of consulting subnational parliaments regarding EU legislation, national legislators 'omit' them by cooperating with regional representatives in the second chamber. In such cases, the controlling functions of subnational parliaments become significantly impeded. While this indicator is relevant for the majority of countries of interest (i.e. possessing legislative parliaments and territorial second chambers such as Germany, Austria, Spain, Italy, and Belgium), it does not apply to the British case, where the House of Lords is neutral with regard to territorial representation.

The above considerations lead to the generation of the third hypothesis: the privileged position of subnational executives in domestic governance arrangements (either through the nature of inter-level decision-making orland through institutionalization of executive representation in the second chamber) will inhibit parliamentary mobilization under the EWS.

\section{Methodology}

This paper uses comparative analysis of the EWS in Spain, Germany, and the United Kingdom. The choice of these case studies was guided by a number of considerations. First, regions enjoy wide law-making competences in various fields of policy in these 
countries and the impact of the EU on the exercise of regional powers is considerable. They also represent states where regional elections play a significant role, voters identify with their regions, and regional politics influences the political dynamics at the national level. However, apart from the similarities, this case selection allows this research to account for different systemic factors that might affect parliamentary mobilization, such as the tradition of intergovernmental relations. Most importantly, there are differences in key factors of interest; that is, the relationship between the executive and legislature at the subnational level and the position of the regional executive in domestic governance arrangements.

This research takes a state, as opposed to a region, as its primary level of analysis, which is dictated by the choice of the analytical framework of Europeanization. However, for the purpose of testing alternative explanations for regional mobilization, a certain degree of disaggregation of the comparison takes place.

\section{The dependent variable}

The concept of subnational parliamentary mobilization is understood here as the institutional and political activities of regional parliaments aimed at gaining control and influence over European affairs in the initial phases of the EU policy cycle based on interaction with other institutional actors (i.e. national parliaments and subnational governments). For the purpose of this research, changes to the dependent variable are measured through a series of the following indicators: the existence at the regional level of formal procedures to conduct subsidiarity scrutiny under the EWS; the number of subsidiarity analyses conducted by parliaments; the number of reasoned opinions issued by them in the framework of the EWS; the number of cases when regional observations were included in the national final opinion; the existence of direct interparliamentary communication and cooperation between the national and subnational level; and finally, subnational parliaments' perception of the EWS in operation. The above-mentioned elements account for the institutional effects as well as changes in actors' preferences and strategies, thus, linking the structural and agency-driven explanations.

\section{Data sources}

This research is based on empirical data gathered from three different sources. The first includes a questionnaire directed at subnational parliaments in Germany, Spain, and the United Kingdom, and addressed by legal advisers responsible for European affairs (most often representing parliamentary EU commissions). In many cases, the questionnaires were complemented by further telephone interviews. The questionnaire was divided into four parts, each enquiring about different aspects of the parliamentary experience in the EWS (detailed information on the questionnaire can be found in supplementary data). Regarding the gathered data, the questionnaires were completed by 20 out of 36 regional parliaments (response rate of 56\%): eight German, nine Spanish, and three UK 
parliaments. ${ }^{5}$ As the response distribution illustrates, the data accounts for different types of regions, including those with stronger cultural identities and economic positions, and those which are less resourceful.

Bearing in mind that the information obtained from parliamentary representatives might present a certain bias, questionnaires were cross-checked with data from official documents related to parliamentary EU activities, such as the existing regulations, statutes, and reports. Regarding tracing the regional parliamentary input into national reasoned opinions, the data were obtained from the inter-parliamentary information exchange system (IPEX), which registers all parliamentary documents under the framework of the EWS. The third set of data consists of informal interviews and desk research carried out in various waves at the Subsidiarity Monitoring Network of the Committee of the Regions between January 2011 and March 2012.

\section{Subnational parliamentary mobilization under the EWS}

\section{Germany}

While German Länder are among the most active regional authorities in EU policymaking, the literature agrees that their parliaments (Landtage) have been considerably marginalized in the sphere of European affairs (Bauer, 2005; Hrbek, 2010). The long tradition of intergovernmental cooperation, tight institutional linkages between the national and regional level, and centralization of German federalism, clearly affect the participation of the Landtage in the EWS (Abels, 2013).

Regarding the first explanatory factor, Länder parliaments do not enjoy any formal rights to information or participation in the EWS established at the federal level. Consequently, no direct channel of communication between the subnational and federal parliaments has been established. Regarding the reception of EU documents necessary to conduct the scrutiny, these are forwarded from the Bundestag to regional executives, bypassing the Landtage. The absence of national-level provisions makes parliamentary scrutiny dependent on the nature of the relations with subnational executives. These have been traditionally based on the domination of the latter (Vara Arribas and Bourdin, 2011). While for a long time governments could be selective in sharing information with their legislatures, only recently have the latter ones gained the right to be informed by their governments in EU affairs (Abels, 2013). The questionnaires reveal that cooperation between the governments and the Landtage has a receptive character, that is, the parliament might ask for the report on particular EU legislative proposals but does not take the initiative in issuing independent opinions. Five out of eight Landtage admitted that it is the

\footnotetext{
${ }^{5}$ In Germany: Berlin, Bavaria, Baden-Württemberg, Bremen, Hessen, Saxony, Lower Saxony, Nordrhein-Westfalen; in Spain: Basque Country, Catalonia, Extremadura, Canary Islands, Galicia, Aragón, Murcia, Andalusia and Cantabria; in the United Kingdom: Wales, Scotland, and Northern Ireland. The data refers to EWS experience in the time period 2011-12.
} 
regional government which takes the lead under the EWS (Bremen, Berlin, Nordrhein-Westfalen, Saxony, Lower Saxony).

This state of affairs is directly connected to the systemic provisions favouring the executive role in domestic governance arrangements. With respect to the nature of the domestic relationship between the subnational and national governments, Jeffery observes that a large part of domestic decision-making in Germany is 'conducted behind closed doors and tends to precook policy away from parliamentary scrutiny, with the Bundestag and the Länder parliaments often effectively relegated to rubberstamping devices' (1997: 45). Kropp, on the other hand, argues that the 'joint decisionmaking' model of German federalism weakens parliaments in yet another way. She points out the fact that if executives do not agree on a common stance in federal negotiations, the Landtage cannot preserve their legislative function by imposing policy solutions, as the executives can 'deviate from parliamentary decisions in order to avoid gridlock' (Kropp, 2015: 7). As regards the second indicator (i.e. the composition of the second chamber), the interests of the Länder, at the federal level, are represented by the Bundesrat fully composed of delegates from regional governments. Bundesrat members are not elected but delegated by their respective land government, which clearly favours regional executives. As the consent of the second chamber is required for well over half of the federal laws, Länder governments perform the legislative function at the federal level. While the subsidiarity check is integrated into the regular decision-making process involving the Bundesrat, the scrutiny and control functions of the Landtage remain significantly impeded.

In terms of the changes to the dependent variable, Länder parliaments have undertaken a series of procedural and organizational adaptations to adjust to the provisions of the Lisbon Protocol. However, the research suggests that the new regulations established at the regional level are weak and mostly lack institutional safeguards. According to the questionnaires, only four Landtage established specific internal procedures to perform the work under the EWS (Bavaria, Baden-Württemberg, North Rhine-Westphalia, and Berlin). The majority relies on non-binding agreements recently negotiated with their governments on the improved information and scrutiny rights in domestic and EU affairs'. These are, however, limited to issues of 'vital importance' for the Länder, which is left to the decision of subnational governments.

The overall regional record of Landtage participation in the EWS is rather poor (around 90 conducted analyses), ranging from no experience so far (Bremen, Nordrhein-Westfalen, Hamburg, Saxony, and Mecklenburg-West Pomerania), through occasional activity (Berlin, Hessen), to regular scrutiny in the case of Bavaria and Baden-Württemberg. Although the example of the latter might point to a resource-push explanation behind parliamentary mobilization, it should not serve to draw generalizations about the overall intra-state pattern. When we control for the constitutional status and disaggregate the comparison to the regional level, the economic strength variable does not really hold, as the Nordrhein-Westfalen Landtage (the highest regional GDP) shows no activity under the EWS, and the Berlin Landtage (eighth GDP) conducts more analyses than the parliament of Lower Saxony (fourth GDP). In this context, we 
should look for additional explanatory factors behind a stronger mobilization of some Landtage, such as, for example, the relative strength of regional political parties (i.e. Bavarian Christian Social Union (CSU) as a coalition partner at the federal level). This small number of analyses might be attributed in part to the fact that regional interests are already well integrated in the member state position via the Bundesrat, which reduces incentives for the regional parliaments to mobilize additional resources in EU affairs. Regarding the number of reasoned opinions issued by the Landtage, only two out of eight parliaments admitted issuing such reports under the EWS (Berlin and Hessen issued altogether six opinions).

In terms of the relative influence of parliamentary opinions, no concrete data exists on the inclusion of parliamentary observations into the opinions of the Bundesrat. As these are Länder governments that involve the Landtage in the EWS, there is no immediate register of parliamentary opinions at the federal level. In the period 2011-12, neither of the federal reasoned opinions referred to the regional parliamentary input (see IPEX). ${ }^{6}$

The existing domestic intergovernmental arrangements also affect the Landtage's perception of their roles in EU policy control. The questionnaires revealed that in spite of the general interest in the procedure, the Landtage do not see themselves as protagonists in EU affairs, but rather accept the primacy of their governments, on which - as underlined - they 'rely in terms of information and expertise' (Bremen). Some of the respondents do not even see the need to reform the existing mechanisms and establish a direct inter-parliamentary channel of communication between the Landtage and the Bundestag or Bundesrat (Berlin and Saxony-Anhalt). There are also sceptical voices describing members of Länder parliaments as 'part-time legislators', who often continue to 'pursue other professions outside the assembly' (Berlin).

\section{Spain}

While European integration has reinforced the Spanish regional executives over legislatures in domestic EU decision-making (Carmona Contreras, 2012), this process has been less institutionalized than in the case of Germany and, therefore, has remained more open to adaptive changes exerted by the EWS. Regarding the first explanatory variable, parliaments of the autonomous communities are included into the EWS through a national-level regulation (Law 38/2010). It grants them information and participation rights and establishes a direct link between the national and regional level legislators via the Joint Commission of the Congress and Senate for the EU. Once autonomous parliaments receive an EU legislative draft, they may draw up a report if they consider that, first, regional competences are affected, and second, the principle of subsidiarity has been violated.

\footnotetext{
6 The list of opinions issued so far by the German Bundesrat on the following EU legislative projects: COM(2010)0369; COM(2011)0654; COM(2011)0793; COM(2011)0828; COM(2011)0897; COM (2012)0010; COM(2012)0011.
} 
Contrary to the German case, Spanish subnational parliaments have priority in obtaining EU documents from the national level, and forward them to their regional governments. Although they are not obliged to consult or adjust their stances with the regional government, the findings reveal that almost all of the interviewed regional parliaments systematically collaborate with the executive branch in subsidiarity checks. Only the Catalan parliament admitted that no cooperation with its regional executive was established under the EWS. Regional respondents have also observed that as a result of the EWS, communication between the executive and legislature has improved and is increasingly based on mutual assistance (Basque Country, Canary Islands). While this is also true in the case of German Länder, in Spain the relationship between the subnational parliaments and governments is based on stronger information and political autonomy of the former. As analysis of subsidiarity has a fundamentally political character, regional executives 'see it crucial to submit EU projects to a political debate within the parliament involving all the political parties' (Basque Country).

Regarding the second factor, that is, the regional executive's position in domestic governance arrangements, contrary to the German case, Spanish subnational governments are not represented in any of the national parliamentary chambers. Instead, the composition of the Spanish Senado favours, albeit weakly, regional parliamentary oversight of national-level decision-making, as $25 \%$ of the senators are appointed directly by subnational parliaments. Yet, as the Spanish Senate is designed as a weaker body of limited decision-making powers, both in domestic as well as European affairs, this territorial link does not allow the Senate to participate in a relevant way in voicing the interests of the autonomous communities in forming the Spanish position before the EU. Regional interests are represented and negotiated at the national level in another body called the Conference on Issues Related with the EU and in the system of Sectoral Conferences. Both the research and literature indicate that while the decisionmaking process within the Conferences is not very well institutionalized, it is significantly politicized due to its dependence on the respective regional majorities (Arbós Marin et al., 2009). Such a state of affairs makes parliamentary scrutiny easier and allows parliaments to at least 'debate' EU policy proposals before they enter into one of the Conferences, which has been confirmed in the questionnaire by the Basque and Catalan representatives.

Regarding the changes to the dependent variable, 15 out of 17 regional parliaments have incorporated new provisions for subsidiarity control into their legal frameworks. To this end, eight of them amended their statutes of autonomy, ${ }^{7}$ while others established specific internal regulations to perform the work under the EWS. Only Murcia and Aragón have not adopted any specific procedures. Yet, paradoxically, Cortes de Aragón is one of the most active parliaments in the EWS, which shows that the presence of formal procedures is not a necessary condition for parliamentary activity.

\footnotetext{
${ }^{7}$ Valencia (2006), Catalonia (2006), Balearic Islands (2007), Andalusia (2007), Aragón (2007), Castilla y León (2007), Navarra (2010), Extremadura (2011).
} 
Although the data regarding subnational parliamentary participation in the framework of the EWS reveal some disproportions among autonomous communities, the overall relative scrutiny record is the highest among the analysed member states (see Table 1). While some parliaments are more selective than others (e.g. Catalonia, Canary Islands), only four have not conducted any analyses so far (Andalusia, Asturias, Balearic Islands, and La Rioja). In the case of Catalonia, it might be that since the parliament conducts its analyses independently of the government, it needs to economize on resources and therefore, carefully selects the types of scrutinized EU dossiers.

The most active are the parliaments of the Basque Country, Aragón, and Extremadura, which account for over $60 \%$ of opinions. Such activity distribution suggests that parliamentary mobilization does not depend so much on the economic strength of a region. While the Basque Country represents the fifth position in terms of the largest regional GDP, Aragón has the ninth GDP and Extremadura is the poorest region of Spain. Moreover, three out of four regions with the highest GDP (i.e. Madrid, Andalusia, and Valencia) have not performed any analyses under the EWS in the analysed period. On the other hand, cultural distinctiveness holds explanatory power in the case of the Basque Country (over 130 analyses) and Catalonia (over 30), but does not hold explanatory power for the quite low activity of Galicia (10). Regarding the inclusion of regional observations into the national opinion, the data extracted from IPEX reveal a positive picture regarding the reception of regional input by the Joint Commission. All reasoned opinions issued by Cortes Generales in the period 2011-12 acknowledged subnational reports referring to concrete parliamentary assemblies. ${ }^{8}$

In terms of the regional perception of the EWS, the majority of respondents emphasize the considerable institutional effort that is required to comply with scrutiny procedures. In contrast to their German counterparts, more Spanish respondents express scepticism as to the effectiveness of the EWS and its design, which 'does not allow to meaningfully influence EU policy process’ (e.g. Basque Country, Canary Islands). Such an attitude might be explained by a greater parliamentary experience that allows for more constructive criticism of the mechanisms in place. Some respondents admitted that due to an increasing number of policy dossiers coming from the EU and the narrow scope of the subsidiarity check, they have become more selective in choosing legislative projects, but at the same time conduct broader analyses including observations about proportionality and policy contents (e.g. Catalonia, Canary Islands, Basque Country). Autonomous legislatures also work on improving domestic parliamentary cooperation by organizing joint training between lawyers working for subnational and national parliaments.

\section{United Kingdom}

The research reveals that although the devolved legislatures of Scotland and Wales have the shortest experience of the EU, their awareness, engagement, and internal

${ }^{8}$ The list of opinions issued by the Mixed Commission referred to the following EU legislative drafts: $\operatorname{COM}(2011) 215$ and 216 on unitary patent protection; $\operatorname{COM}(2011) 0169$ on taxation of energy products and electricity; $\operatorname{COM(2011)896~and~} 897$ on public procurement; $\operatorname{COM(2012)167~on~European~statistics.~}$ 
Table 1. Components of the dependent variable under the early warning system (EWS)

\begin{tabular}{|c|c|c|c|c|c|c|}
\hline $\begin{array}{l}\text { Time per- } \\
\text { iod ana- } \\
\text { lysed: } \\
(2011-12)\end{array}$ & $\begin{array}{l}\text { Presence of formal procedures } \\
\text { at the regional level/number of } \\
\text { regional parliaments }\end{array}$ & $\begin{array}{l}\text { Number of subsi- } \\
\text { diarity analyses } \\
\text { conducted under } \\
\text { EWS }^{\mathrm{b}}\end{array}$ & $\begin{array}{l}\text { Number of reasoned } \\
\text { opinions issued by the } \\
\text { regional parliaments }\end{array}$ & $\begin{array}{l}\text { Number of regional } \\
\text { opinions included } \\
\text { into national opinions }\end{array}$ & $\begin{array}{c}\text { Existence of inter- } \\
\text { parliamentary cooperation } \\
\text { between the national and } \\
\text { regional level }\end{array}$ & $\begin{array}{l}\text { Perception of the } \\
\text { EWS by regional } \\
\text { parliaments }\end{array}$ \\
\hline Spain & $15 / 17$ & $\sim 370$ & 7 & 7 & Yes, formalized & $\begin{array}{l}\text { Sceptical, } \\
\text { looking for } \\
\text { improvements }\end{array}$ \\
\hline $\begin{array}{l}\text { United } \\
\text { Kingdom }\end{array}$ & $2 / 3$ & 40 & 5 & 5 & Yes, informal & $\begin{array}{l}\text { Critical, looking } \\
\text { for other routes } \\
\text { of influence }\end{array}$ \\
\hline Germany & $4 / 16$ & $\sim 90$ & 6 & No data & No & Positive \\
\hline
\end{tabular}

${ }^{a}$ The data regarding the presence of formal procedures for subsidiarity scrutiny at the regional level include all regional parliaments in a member state and is based on official institutional documents.

${ }^{\mathrm{b}}$ In Spain and Germany, some parliaments would give only approximate answers regarding the number of subsidiarity analyses conducted under EWS. 
specialization in the field of European affairs is relatively well advanced. This might be due to the fact that, as young parliaments, they had to face the challenge of extensive Europeanization already at the time of their establishment. In the case of the Northern Ireland Assembly (NIA), its parliamentary experience was suspended between 2002 and 2007 due to political unrest.

The degree of devolution in the United Kingdom is asymmetrical, although the impact of EU law on the exercise of devolved matters is considerable in each of the regions. ${ }^{9}$ For this reason, there is an unwritten agreement that they should be involved in the EU policy-making process in matters affecting their competences (Bulmer et al., 2006).

Regarding the first explanatory factor, the British provisions for parliamentary participation in the EWS lie halfway between the formally institutionalized arrangements present in Spain and the absence of any facilitating mechanisms in Germany. In terms of the right to information, all documents necessary to conduct scrutiny under the EWS are transmitted to regional parliaments via the United Kingdom and devolved governments. At this stage, there is no direct contact between the regional assemblies and the Houses of Parliament. The UK government, in consultation with the devolved executives, has priority in elaborating EU draft legislation and issuing explanatory memoranda outlining their positions on the proposals. Yet, in spite of the absence of formal rules for cooperation between the UK parliament and the devolved legislatures under the EWS, the House of Commons, European Scrutiny Committee, in its 2008 report on 'Subsidiarity, National Parliaments and the Lisbon Treaty', placed responsibility on the devolved assemblies to examine EU draft legislation and inform the House about possible objections (House of Commons, European Scrutiny Committee, 2008: 14). It also invited comments of the devolved assemblies on the Committee's draft opinions on matters affecting their competences. Additionally, the House of Lords elaborated a handbook on EU policy scrutiny stating that if a subsidiarity issue is raised at staff level, the EU Liaison Officer will alert the devolved legislatures in due time. EU committees of both Houses have also agreed to receive and translate the subsidiarity concerns of the Scottish parliament (Vara Arribas and Bourdin, 2011).

Although the national-level arrangements favour the devolved executives regarding the right to information, participation, and representation of the regional position in EU affairs, in order to rebalance the relationship between legislature and executive at the subnational level, devolved parliaments were granted more robust institutional structures and controlling powers than those enjoyed by their German or Spanish counterparts (cf. Randall and Seawright, 2002). Regarding the 'working relationship' between the devolved executive and legislature, the Scottish and Welsh parliaments have developed a relatively strong controlling position in the ex ante

\footnotetext{
9 The Scotland Act of 2012 extended the Scottish legislative competences to new policy areas and granted it further fiscal devolution; the Government of Wales Act of 2006 conferred legislative authority to the Welsh Assembly, which was approved in the 2011 referendum.
} 
review of EU policy as well as good communication with regional executives (Fasone, 2012). In order to gain more independence vis-à-vis their regional executives, both devolved legislatures invested considerable effort to set up specialized EU committees and establish direct links with Brussels. This facilitates the accumulation of expert knowledge and an internal division of labour that aids parliaments when dealing with complex European policy issues. In spite of the initial organizational and capacity problems, the two assemblies have managed to develop an early engagement approach based upon intelligence gathering in order to perform the correct oversight of their governments (Carter and McLeod, 2005). To ensure their legislative control, they developed procedures to hold the executive to account for its actions in the European field, as ministers might be called to provide evidence to EU parliamentary committees on their work (Vara Arribas and Bourdin, 2011: 129). This process was gradually facilitated by subnational governments, who agreed to share more information with their legislators. The situation looks different in the case of the NIA. According to the received questionnaire, internal arrangements for EU scrutiny in the NI Government are still in the early stages themselves and, at this point, there is generally no willingness to cooperate or provide the assembly with information on EU-related issues.

The cooperative relation between the executive and legislature is especially important in the light of the second explanatory factor, that is, the position of the regional executive in domestic governance arrangements, which makes effective parliamentary scrutiny difficult to achieve. The two main challenges are the informal and ad hoc nature of a large part of intergovernmental negotiations and the emphasis on confidentiality (Högenauer, 2012). As revealed by the questionnaires, implementation of the EWS into the domestic order reflects these patterns, as it is often based on informality, flexibility, and unwritten codes of conduct. In this regard, the Scottish respondent noticed that 'informal contacts with staff members of the UK parliament play an important role in EU policy control'. As to the second aspect of this variable, the composition of the House of Lords is currently neutral to subnational parliamentary mobilization because it is not a territorial second chamber. In the future, however, one could reasonably expect the introduction of a territorial component in the second chamber due to the progress of devolution (Russel, 2001).

In terms of the changes to the dependent variable, the research reveals that while the initial phase of implementation of the EWS uncovered a number of weaknesses in the parliamentary scrutiny, it also allowed for substantial improvements. According to the questionnaires, the assemblies of Scotland and Wales established their internal scrutiny procedures and perform analyses under the EWS. The NIA is currently designing a new process for subsidiarity scrutiny. In Wales, the Committee for European Affairs adopted a strategic approach based on identifying and scrutinizing those EU proposals that are most relevant for regional interests. The Scottish Parliament appointed a special EU reporter to liaise directly with 
other institutional actors, that is, regional governments and the UK parliament (Scottish Parliament, 2010).

Regarding the scrutiny record, the years 2011-12 witnessed an increase in the number of analysed EU proposals. According to the reports issued by the European and External Relations Committee, out of all analysed EU dossiers, the Scottish parliament identified three EU legislative proposals as raising subsidiarity concerns and communicated its views to the House of Lords and House of Commons. ${ }^{10}$ The National Assembly of Wales indicated that its legal services analysed 29 EU draft legislative acts under the EWS. Out of these, one was identified as raising subsidiarity concerns. ${ }^{11}$ The NIA has so far issued one reasoned opinion, ${ }^{12}$ which also indicates that formal procedures are not an indispensable element of parliamentary participation in the EWS. Asked about the main challenge to operationalize the EWS at the regional level, ${ }^{13}$ the representative of the NIA mentioned, next to administrative weakness, lack of cooperation with the regional government.

Although the UK parliament is under no formal obligation to accept the views expressed by the devolved legislatures under the EWS, the hitherto experience reveals its receptiveness. So far, in all the above-mentioned cases, reports of the devolved assemblies were taken into account in the final national opinions (IPEX database). The stronger parliamentary mobilization of the Welsh assembly over the Scottish one challenges the resource-push explanation (the Scottish region is more resourceful in terms of regional GDP and budget). Yet, it might be explained by the longer EU experience of the latter and the resulting parliamentary perception of the effectiveness of the EWS. As the Scottish interviewee explained: 'I would argue that it [EWS] has not been a success, either at a national or a regional level. The amount of effort required from all levels within a parliament to provide an opinion is considerable. Where a parliament feels strongly about an issue, there are other avenues for seeking change at earlier stages; seeking to change a draft legislative proposal is too late'. Such an attitude is linked to a broader EU parliamentary strategy based on seeking external influence in European affairs through pre-legislative lobbying and networking in Brussels, often bypassing the national level.

\section{Summary and conclusion}

This paper intended to shed light on cross-country differences in subnational parliamentary activity under the EWS by placing an increased focus on the mediating role of domestic institutions. At the very least, it presented a theoretical framework that can help to understand the contextual factors affecting parliamentary activity in EU affairs. By applying the 'domestic lens' of

${ }^{10}$ On EU legislative drafts: $\operatorname{COM}(2012) 0034$ on distribution of food products to the most deprived persons in the EU; $\operatorname{COM}(2011) 0896$ and $\operatorname{COM}(2011) 0897$ on public procurement.

$11 \mathrm{COM}(2011) 0896$ on public procurement.

12 Draft regulation on periodic roadworthiness COM(2012)380.

13 Question 21 in the questionnaire. 
Europeanization, this paper tried to explain why the scope of subnational parliamentary mobilization varies between the analysed states, being relatively strongest in Spain, weaker in the United Kingdom, and the weakest in Germany (see Table 1).

A detailed analysis of the domestic contexts implies that the changes to the dependent variable might be conditioned by a combination of two institutional factors: the relationship between the executive and legislature at the subnational level and the position of the subnational executive in domestic governance arrangements (see Table 2).

Regarding the first factor, the existence of formal provisions for parliamentary engagement at the national level seems to facilitate subnational mobilization under the EWS. While in Spain, parliaments obtained information and participation rights from the very beginning, the relationship between the devolved governments and parliaments in the United Kingdom has gradually evolved from the domination of the executives towards a stronger parliamentary scrutiny of EU legislation. Although the devolved executives enjoy information priority under the EWS, these are the parliaments whose reasoned opinions are taken into account at the national level. On the other hand, in Germany, lack of formal provisions for Landtage and domination of Länder governments under the EWS effectively impede parliamentary activity. The adaptation that occurs lies more in the internal parliamentary organization and only very slowly extends to a change in legislativeexecutive relations.

The research also indicates that parliamentary mobilization is more likely when accompanied by cooperative relations between the regional executive and legislature. At the same time, the breaking down of this variable in some regional cases suggests that lack of cooperation with the regional government might be a hampering factor of engagement with the EWS or results in a more selective approach to EU scrutiny. This argument should, however, be developed on a wider set of cases.

The second factor might be especially important in Germany, where the dominating position of regional executives in domestic governance arrangements evidently stymies subnational parliamentary mobilization under the EWS. Additionally, the character of federal EU decision-making conducted 'behind closed doors' in the executive-dominated Bundesrat institutionalizes the legislative function of regional executives, further weakening the EU involvement of Landtage. German arrangements, as opposed to the Spanish and British, lack direct communication between federal and state parliaments.

In the case of Spain, a transparent and open to parliamentary scrutiny relationship between regional governments and national executives, as well as the composition of the second chamber, further facilitate parliamentary engagement in the EWS. In the United Kingdom, the activity of the devolved parliaments was initially hampered by the gate-keeping position of regional executives as well as by the confidential and informal character of intergovernmental relations between the devolved and UK governments. However, with time, inter-level parliamentary communication has been facilitated by informal contacts between the devolved parliaments and the Houses of Parliament. 
Table 2. Distribution of independent variables across the analysed cases

\begin{tabular}{|c|c|c|c|}
\hline \multirow[b]{3}{*}{ Member state } & \multicolumn{3}{|c|}{ Independent variables } \\
\hline & \multicolumn{2}{|c|}{ Relationship between the executive (SE) and legislature (SL) } & \multirow[b]{2}{*}{$\begin{array}{l}\text { Position of subnational executive in domestic } \\
\text { governance arrangements }{ }^{\mathrm{a}}\end{array}$} \\
\hline & $\begin{array}{l}\text { Existence of information and } \\
\text { participation rights for regional } \\
\text { parliaments under the EWS }\end{array}$ & $\begin{array}{l}\text { Character of working relations } \\
\text { under the EWS }\end{array}$ & \\
\hline Spain & Yes, formalized & $\begin{array}{l}\text { Cooperation/information and expertise sharing/ } \\
\text { independence of SL }\end{array}$ & $\begin{array}{l}\text { Inter-level decision-making open to parliamentary } \\
\text { scrutiny/weakly institutionalized/no governmental } \\
\text { representatives in the second chamber }\end{array}$ \\
\hline United Kingdom & Yes, informal & $\begin{array}{l}\text { Increasing cooperation/selective information } \\
\text { sharing/partial dependence of SL }\end{array}$ & Inter-level decision-making confidential/informal/Ø \\
\hline Germany & No & $\begin{array}{l}\text { Increasing cooperation/from monopolization of } \\
\text { information by SE to selective sharing/ } \\
\text { dependence of SL }\end{array}$ & $\begin{array}{l}\text { Inter-level decision-making conducted behind closed } \\
\text { doors/strongly institutionalized } / 100 \% \text { of the second } \\
\text { chamber represent Länder governments }\end{array}$ \\
\hline
\end{tabular}

EWS = early warning system.

${ }^{\text {a }}$ This factor refers to domestic governance arrangements in a broader context of EU affairs. 
While the composition of the House of Lords does not influence subnational parliamentary mobilization, it might be expected that future reforms will introduce territorial representation in the second chamber, which might have an effect on the position of the devolved parliaments (Russel, 2001).

As it is difficult to pinpoint with any precision which of the discussed variables is more important in the analysed countries, further research should explore these questions on a wider number of cases.

Regarding changes over time, in spite of the relatively short history of the EWS in operation, several scenarios might be expected. According to the rational choice approach, with more experience and resources at hand, regional parliamentary mobilization should increase, especially in countries where regional opinions are taken into account at the national level. On the other hand, longer experience with the EWS might result in increasing scepticism or more selective parliamentary strategies of EU scrutiny. This trend can already be noticed in the case of Spain and the United Kingdom. Regarding Germany, in line with path dependency arguments (cf. Abels, 2013), we might expect that while the Landtage try to accommodate their internal structures, their relations with governments and the federal parliament will not restructure fundamentally.

Looking at the configuration of the discussed domestic-level variables across other member states, we could hypothesize how the presented findings can travel to most similar cases. While in Austria, members of the Bundesrat are elected by regional parliaments, we could expect a stronger parliamentary mobilization in the EWS. The research also reveals that mobilization occurs despite weaker competences where national-level provisions for parliamentary engagement exist. In this sense, the recent introduction of a national-level regulation in Italy granting regional parliaments participation rights in the EWS might positively influence parliamentary mobilization. Finally, Belgian subnational parliaments should be expected to mobilize strongly as they theoretically function on par with the federal parliament in terms of their scrutiny rights. On the other hand, lack of formal procedures institutionalizing these rights might impede their mobilization.

The empirical data also reveal sharp contrasts in intra-state parliamentary activity, especially in Germany and Spain. This is of immense value in testing alternative factors, as variations among regional parliaments cannot be explained by national-level variables that do not vary across regions. In searching for these explanations, it was found that once the constitutional set up is controlled, no clear pattern of parliamentary mobilization emerges. The differences among parliaments are not easily explainable through individual-level factors such as the economic position of a region or its cultural distinctiveness. It seems that the intra-state variations in parliamentary mobilization are much more complex and might involve other factors that have not been addressed in this study, such as political configuration of the parliament, political entrepreneurship of individual members of parliament, regional parties' attitudes towards the EU, and, finally, the level of 
policy salience. For this reason, further comparative research is needed to confront and develop the proposed theoretical framework.

\section{Acknowledgements}

The author would like to thank Adrienne Héritier, Peter Bursens, Michaël Tatham, and Anna-Lena Högenauer for their valuable feedback and advice on the draft versions of this paper.

\section{Supplementary material}

To view supplementary material for this article, please visit http://dx.doi.org/ $10.1017 /$ S1755773915000375

\section{References}

Abels, G. (2013), 'Adapting to Lisbon reforming the role of German Landesparlamente in EU affairs', German Politics 22(4): 1-28.

Arbós Marín, X., C. Colino Camara, M.J. Morales and S. Parrado Diez (2009), Las relaciones Intergubernamentales en el Estado autonómico. La posición de los actores, Generatlitat de Catalunya, Barcelona: Institut di Estudis Atonomics.

Bauer, M. (2005), 'Europaausschüsse - Herzstück landesparlamentarischer Beteiligung in Angelegenheiten der Europäischen Union?', Jahrbuch des Föderalismus 2005, Baden-Baden: Nomos, pp. 632-647.

Bauer, M., D. Pitschel and P. Studinger (2010), 'Governance preferences of subnational administrative elites in the European Union'. Working Paper Series No. 4, Lehrstuhl Politik und Verwaltung.

Blatter, J., M. Kreutzer, M. Rentl and J. Thiele (2009), 'Preconditions for foreign activities of European regions: tracing causal configurations of economic, cultural, and political strategies', Publius: The Journal of Federalism 40(1): 171-199.

Borońska-Hryniewiecka, K. (2013), 'Regions and subsidiarity after Lisbon: overcoming the regional blindness?', in M. Cartabia, N. Lupo and A. Simoncini (eds), Democracy and Subsidiarity in the EU. National Parliaments, Regions and Civil Society in the Decision-Making Process, Series of Nova Universitas, Bologna: Il Mulino, pp. 337-364.

Börzel, T. (1999), 'Towards convergence in Europe? Institutional adaptation to Europeanization in Germany and Spain', JCMS 37(4): 573-596.

Börzel, T. and T. Risse (2000), 'When Europe hits home: Europeanization and domestic change', EIOP 4: 15.

Bulmer, S., M. Burch, P. Hogwood and A. Scott (2006), 'UK devolution and the European Union: a tale of cooperative asymmetry?', Publius: The Journal of Federalism 36(1): 75-93.

Bursens, P. (2008), 'State structures', in P. Graziano and M.P. Vink (eds), Europeanization. New Research Agendas, Basingstoke: Palgrave Macmillan, pp. 115-126.

Bursens, P. and J. Deforche (2007), 'Europeanization of subnational polities: the impact of domestic factors on regional adaptation'. European Union Studies Association Tenth Biennial International Conference, May 17-19, Montreal.

Bursens, P., F. Maes and V. Matthias (2013), 'Playing the next level of the multilevel parliamentary game. An outline for research avenues by adding the regional level'. 7th ECPR General Conference, September 4-7, Bordeaux.

Callanan, M. (2012), 'Domestic governance arrangements and Europeanization: the case of central local relations in England, Ireland and Denmark', Comparative European Politics 10(4): 399-420. 
Carmona Contreras, A.M. (2012), 'Hacia la europeización de los parlamentos autonómicos? Reflexiones al hilo del mecanismo de alerta temprana', Revista d'estudis autonòmics i federals 16: 141-176.

Carter, C. and A. McLeod (2005), 'The Scottish parliament and the European Union: analysing regional parliamentary engagement', in S. Weatherill and U. Bernitz (eds), The Role of Regions and Subnational Actors in Europe, Oxford: Hart Publishing, pp. 67-88.

Cooper, I. (2012), 'A “virtual third chamber” for the European Union? National parliaments after the Treaty of Lisbon', West European Politics 35(3): 441-465.

Crum, B. and J.E. Fossum (2009), 'The multilevel parliamentary field: a framework for theorizing representative democracy in the EU', European Political Science Review 1(2): 249-271.

Donas, T. and J. Beyers (2013), 'How regions assemble in Brussels: the organizational form of territorial representation in the European Union', Publius: The Journal of Federalism 43(4): 527-550.

Fasone, C. (2012), 'What role for regional assemblies in regional states? Italy, Spain and United Kingdom in comparative perspective', Perspectives on Federalism 4(2): 171-216.

Featherstone, K. and C. Radaelli (2003), The Politics of Europeanization, Oxford: University Press.

Heggie, G. (2006), 'The Scottish parliament and the EU constitution: moving beyond the principle of partnership', in P. Kiiver (ed.), National and Regional Parliaments in the European Constitutional Order, Groningen: Europa Law Publishing, pp. 29-54.

Hocking, B. (1997), 'Regionalism: an international relations perspective', in M. Keating and J. Loughlin. (eds), The Political Economy of Regionalism, London: Frank Cass, pp. 90-111.

Högenauer, A. (2012), 'The Scottish parliament - active player in a multilevel European Union?'. International Workshop Subnational Parliaments in the EU Multi-Level Parliamentary System, November, Eisenstadt.

- (2014), 'All by themselves? Legislative regions and the use of unmediated access to the European level', European Political Science Review 6(3): 451-475.

House of Commons, European Scrutiny Committee (2008), HC 563, Thirty-Third Report of Session 2007-8, October, Retrieved 14 June 2013 from www.publications.parliament.uk/pa/cm200708/ cmselect/cmeuleg/563/563.pdf

Hrbek, R. (2010), 'Parliaments in EU multi-level governance', in R. Hrbek (ed.), Legislatures in Federal Systems and Multi-Level Governance, Baden-Baden: Nomos, pp. 136-150.

Jeffery, C. (1996), 'Regional information offices in Brussels and multi-level governance EU: A UK-German comparison', Regional \& Federal Studies 6(2): 183-203.

_ (1997), 'The decentralisation debate in the UK: role-model Deutschland?', Scottish Affairs 19: 42-54. (2000), 'Sub-national mobilization and European integration: does it make any difference?', JCMS 38(1): 1-23.

Keating, M. and L. Hooghe (2006), 'Bypassing the nation-state? Regions and the EU policy process', in J. Richardson (ed.), European Union: Power and Policy-Making, London: Routledge, pp. 269-286.

Kropp, S. (2015), 'Federalism and subnational parliaments - a delicate relationship?', In G. Abels and A. Eppler (eds), Subnational parliaments in an EU multi-level parliamentary system: taking stock of the Post-Lisbon Era, Foster Europe International Studies Series vol. 3, New Jersey, USA: Studienverlag Innsbruck und Transaction Publishers.

March, J.G. and J.P. Olsen (1989), Rediscovering Institutions, New York, NY: Free Press.

Marks, G., R. Haesly and H. Mbaye (2002), 'What do subnational offices think they are doing in Brussels?', Regional and Federal Studies 12(3): 1-23.

Marks, G., F. Nielsen, L. Ray and J. Salk (1996), 'Competencies, cracks, and conflicts: regional mobilization in the European Union', Comparative Political Studies 29(2): 164-192.

Moore, C. (2007), 'The impact of devolution on EU level representation: British regional offices in Brussels', Regional and Federal Studies 17(3): 275-291.

Neyer, J. (2014), 'Justified multi-level parliamentarism: situating national parliaments in the European Polity', The Journal of Legislative Studies 20(1): 125-138.

Olsen, J.P. (2009), 'Change and continuity. An institutional approach to institutions of democratic government', European Political Science Review 1(1): 3-32.

Palomares Amat, M. (2011), 'La participación del parlamento de Cataluña en la aplicación y el control del principio de subsidiariedad', Revista de Derecho Comuniatrio Europeo 33: 19-59. 
Peters, B.G. (2000), Institutional theory: problems and prospects, Political Science Series 69 Vienna: Institute for Advanced Studies.

Pierson, P. (2000), 'Increasing returns, path dependence, and the study of politics', American Political Science Review 94(2): 251-267.

Radaelli, C. (2003), 'The Europeanization of public policy', in K. Featherstone and C. Radaelli (eds), The politics of Europeanization, Oxford: Oxford University Press, pp. 27-57.

Randall, N. and D. Seawright (2002), 'Merely a talking shop? The European Committees of the Scottish parliament and Welsh Assembly: new politics in a system of multi-level governance?'. Annual Conference of the Political Studies Association, University of Aberdeen, April 5-7.

Raunio, T. (2007), 'National parliaments and the future of European integration: learning to play the multilevel game', in J. DeBardebeleben and A. Hurrelmann (eds), Democratic Dilemmas of Multilevel Governance: Legitimacy, Representation and Accountability in the European Union, Basingstoke: Palgrave, pp. 159-176.

Rowe, C. (2011), Regional Representations in the EU. Between Diplomacy and Interest Mediation, Basingstoke: Palgrave Macmillan.

Russell, M. (2001), 'The territorial role of second chambers', The Journal of Legislative Studies 7(1): 105-118.

Scottish Parliament (2010), '4th Report of the European and External Relations Committee (Session 3), Inquiry into the Impact of the Treaty of Lisbon on Scotland'. Retrieved 30 May 2012 from www. archive.scottish.parliament.uk/s3/committees/europe/reports-10/eur10-04-01.htm

Selznick, P. (1957), Leadership in Administration, New York, NY: Harper \& Row.

Swenden, W. (2004), Federalism and Second Chambers: Regional Representation in Parliamentary Federations: The Australian Senate and German Bundesrat Compared, New York, NY: Peter Lang. (2010), 'Subnational participation in national decisions: the role of second chambers', in H. Enderlein, S. Wälti and M. Zürn (eds), Handbook On Multi-Level Governance, Cheltenham: Edward Elgar, pp. 103-122.

Tatham, M. (2010), 'With or without you? Revisiting territorial state-bypassing in EU interest representation', Journal of European Public Policy 17(1): 76-99.

- (2011), 'Devolution and EU policy-shaping: bridging the gap between multi-level governance and liberal intergovernmentalism', European Political Science Review 3(1): 53-81.

Vara Arribas, G. and D. Bourdin (2011), The Role of Regional Parliaments in the Process Of Subsidiarity Monitoring Within the Early Warning System of the Lisbon Treaty, Brussels: Committee of the Regions. 